\title{
Information and Communication Technologies for Transforming Agricultural Production and Rural Income of Women Farmers in Orlu Agricultural Zone of Imo State, Nigeria
}

\author{
Okereke - Ejiogu NE1, Chikaire JU1', Nnadi FN1 and Emerhirhi \\ Emily2* \\ ${ }^{1}$ Department of Agricultural Extension, Federal University of Technology, Nigeria \\ 2Department of Agricultural Education, Federal College of Education, Technical, \\ Nigeria
}

Research Article

Volume 3 Issue 4

Received Date: July 30, 2018

Published Date: September 24, 2018

*Corresponding author: Emerhirhi Emily, Department of Agricultural Education, Federal College of Education, Technical, Omoku, Rivers State, Nigeria, Email: akjamin2010@gmail.com

\section{Abstract}

ICTs when harnessed meaningfully can remedy the ailments and challenges facing rural poor farmers. This is true because ICTs have a strong focus on improving the wellbeing of rural communities and rural farm families; reducing poverty; sustaining environmental resources; and achieving food security. This study examined ICT potentials to transform and empower rural women farmers in Imo State Nigeria. Purposive random sampling technique was used to select 130 ICT user women farmers in the study area. Structured questionnaire was used to collect data and analysis was done using percentages, mean and standard deviation. The commonest ICT devices used includes mobile phones (100\%) and radio (99.2\%). ICT capability includes its use for product advertising $(\mathrm{M}=3.20)$, delivering information about selling products $(M=2.84)$, improving interaction $(M=2.82)$, improving production systems $(M=3.14)$, help farmer cooperatives organize $(\mathrm{M}=2.82)$ and others. The following were constraints to use of ICT- high cost of hardware (98.5\%), access to energy (93.4\%), programs not meeting needs (91.5\%). To address the above, regular training, reduced cost of hardware, provision of energy and improve network coverage be vigorously pursued to enhance farmer productivity.

Keywords: ICT; Income; Rural; Capability; Farmers

Abbreviations: GDP: Gross Domestic Product; MDGs: Millennium Development Goals; MDGs: World Food Summit; SSA: Sub-Saharan Africa; ICTs: Information and communication technologies; LGAs: Local Government Areas.

\section{Introduction}

The agricultural sector has been described as the engine for economic growth and improved livelihoods in Nigeria and Africa at large [1,2]. The majority of the 


\section{Food Science and Nutrition Technology}

population in Sub-Saharan Africa lives in rural areas and depends directly or indirectly on agriculture [2]. Agriculture contributes about $17 \%$ to the Gross Domestic Product (GDP) of many of these countries and accounts for $40 \%$ of their exports, apart from contributing to employment creation. According to the UNDP (2005) [3], about one third of the continent's population is malnourished. Africa is the only continent where food production is falling, and like the rest of the world, Africa needs to attain the Millennium Development Goals (MDGs) and the World Food Summit (WFS) goals to reduce the number of hungry people from 790 million to 400 million by 2015. Most of the food grown in Africa is produced by smallholders.

Small-scale agriculture and the harvesting of natural resources provide livelihoods for over $70 \%$ of the African population. Between $70-80 \%$ of this population lives in the rural areas and farmers are predominantly women. Small-scale farmers have certain defining characteristics: they derive their livelihood from holdings of less than 2-5 hectares (usually less than 2 hectares), in normal circumstances they own between 10 to 20 heads of livestock, although often, they have less than 2 or none at all [4]. Small-scale farmers also tend to practice a mix of commercial and subsistence production (in crops and / or livestock). The family provides the majority of labour, while the farm provides the principle source of income $[5,6]$.

To improve productivity, these smallholders need access to improved technologies, best practices, and to appropriate, timely and comprehensive information and knowledge on production, value addition and markets. The FAO (2000) [7] asserts that information and knowledge play a key role in ensuring food security and sustainable development'. Thus, ICTs are considered to be cross-cutting drivers of change for rural and agricultural development, by connecting rural and remote communities, and improving healthcare, education and agricultural productivity [8]. ICTs can, for example, speed up the extension of development services; can be instrumental in strengthening partnerships and in providing a framework for shared learning [9].

Smallholder farmers are essential to food security and livelihoods in rural Sub-Saharan Africa (SSA). Representing an estimated $80 \%$ of SSA farms and $90 \%$ of the region's agriculture production, the typical African smallholder farmer earns income from a few hectares of land, owns about 10-20 animals, and often engages in both commercial and subsistence farming [10,11]. The contributions of smallholder farmers are also integral to economic development as they add up to one third of the continent's gross domestic product [1]. Although crucial to their Communities and the region as a whole, smallholder farmers face enormous challenges to their well-being, including climate change adaptation, food insecurity, and poverty [12].

Information and communication technologies (ICTs) are a unique tool in the arsenal against poverty, which is exacerbated by weak market links, high transportation costs, and price volatility. ICTs have been associated with an increase in efficiency, productivity, and communication between buyers and sellers while reducing waste and price dispersion [13-15]. More recent technologies, such as cell phones and increased internet access have the potential to democratize information access, especially in places where communication infrastructure is lacking.

Given that the future of food depends to such a great extent on small-scale agriculture, governments and development partners are focusing on how to increase productivity in sustainable ways through new technologies that smallholders can use. Irrigation management, biotechnologies, pest management and eradication, soil assessment, improved nutrient and land management, improved market access, and innovative storage facilities are all strategies for increasing smallholders' agricultural productivity and improving their access to markets, but the challenge lies in ensuring that smallholders can obtain and use them. ICT provides an incredible opportunity to reach farmers with the technical information they require to increase yields. Good farming practices maximize chances of a good harvest. In the past, conventional farming practices treated entire farms as homogeneous units even though they are often variable in productive potential. This view is changing as technology allows producers to measure soil nutrient status, crop potential, pasture health, and water-use efficiency at specific sites within a field. ICTs like digital soil maps provide extensive soil information that can be stored and accessed online. GPS, satellite imagery, remote sensors, and aerial images help to assess soil and land variations, and mobile applications and the Internet can disseminate the information quickly.

Therefore, in the study area, the above is not known and the information on effects of use of ICTs on farmers' agricultural practices and their welfare is yet to be established and this is why this study was carried out. The main objective of this study is to determine roles of Information and Communication Technologies (ICTs) in transforming agricultural production and improving rural income among women farmers in Imo State, Nigeria. The 
specific objectives of this study included to: i. identify ICT devices available to the women farmers; ii. Determine ICTs roles in agricultural production transformation and improving rural income among women on farmers in the area; iii. Identify constraints facing the respondents' use of ICT devices for rural income creation and iv. Ascertain strategies for improvement in use of ICTs for rural income creation in the study area.

\section{Methodology}

The study was carried out in Orlu Agricultural zone of Imo state. The state is in South-east Nigeria. Imo state is divided into three (3) senatorial districts of Owerri, Orlu and Okigwe politically and demarcated along three Agricultural Zones namely; Okigwe, Owerri and Orlu [16]. The state is made up of twenty-seven (27) Local Government Areas (LGAs) and its capital is Owerri. Orlu Agricultural Zone is made up of eleven (11) LGAs. Imo state lies within latitudes $4045 \mathrm{~N}$ and $7015 \mathrm{~N}$ and longitudes $66^{0} 50^{\circ} \mathrm{N}$ and $7^{02} 5^{\circ} \mathrm{E}$ with an area of around $5,100 \mathrm{sq} / \mathrm{km}$. It is bordered by Abia State on the East, by the River Niger and Delta State on the West, by Anambra State to the North, and River State to the South [16]. The estimated population of Imo State as of 2016 was 4.8 million and the population density varies from 230 1,400 people per square kilometer (NPC, 2006). It lies within the tropical rain and evergreen forest with a tropical climate that is humid all year round. The rainy season spans from March to October and is bimodal with a two-week break in rainfall in August (August break). The main annual rainfall in the state is $20,00 \mathrm{~m}$ while the annual temperature is between $250 \mathrm{C}$ and $280 \mathrm{C}$ with relative humidity of about $98 \%$ during the raining season and between $50 \%$ and $60 \%$ during dry season. The major arable crops grown are cassava, yam, plantain/banana, maize, melon, sweet potato and vegetables such as okra, pepper, tomato and telfairia. Orlu agricultural zone has 10 Extension blocks and 107 extension circles manned by extension agents. All ICT user women farmers in the zone constitute the population of the study. A list of all registered ICT user women farmers in the zone was obtained from ADP office in the zonal headquarters. The list has a total number of 1,300 ICT user women farmers and $10 \%$ of the total number was randomly selected which gave a total sample size of 130 ICT user women farmers. The study made use of both primary and secondary data. The primary data were collected from field investigation or survey using structured questionnaires and interview schedule. Secondary data sources were utilized to provide background information and other necessary to achieve some objectives of the study. Such secondary data includes textbooks, reports, journals, publications and proceedings. Enumerators were trained and used. Basically, data were analyzed using descriptive statistical tools such as mean, standard deviation, and percentages. Objectives 1 and 3 were analyzed using percentages. A four (4) point Likert type scale of Strongly Agreed (SA), Agreed (A), Disagreed (D) and Strongly Disagreed (SD) assigned values of 4, 3, 2 and 1 was used to analyze objectives 2 and 4 . The values were added and divided by 4 to get the discriminating mean value of 2.50. Any mean value equal to or above 2.50 was regarded as a ICT roles in creating rural income and strategy for improvement, while values less than 2.5 were not regarded as roles and strategies.

\section{Results and Discussion}

\section{ICT Devices Available to Women Farmers in the Study Area}

Table 1 revealed that several ICT tools/devices were used by the respondents. These include mobile phone with $100 \%$ response, radio (99\%) this, is via radio farmer programme, television (89.6\%), newspapers (52.8\%), magazines $(34.6 \%)$ among other devices. This agrees with research literature that ICT is an electronic and interactive bridge between farmers and extension workers [17]. It assists farmers to plan market so as to obtain better price for produce and it also save from exploitations from the middlemen, who uses the prevailing information-gap [18]. Among modern ICTs, mobile phones serves as a means for effective transfer of knowledge and information about agricultural market and technology to farmers that enable them to apply the knowledge directly to improve their farming output and make easy access to market[19]. In addition, motivating farmers in adoption of new agricultural technologies remained a focal point of the agricultural extension [20]. The use of mobile phones and Email had positive impact on farm production of small farmers [21].

\begin{tabular}{|c|c|}
\hline Devices & Percentage \\
\hline Mobile phone & 100 \\
\hline Radio & $99: 00: 00$ \\
\hline Television & 89.6 \\
\hline Internet & 10.8 \\
\hline Computer & 9.2 \\
\hline Video & 1.7 \\
\hline Fax & 1.2 \\
\hline Newspapers & 52.8 \\
\hline Magazines & 34.6 \\
\hline CD Rom & 1.2 \\
\hline
\end{tabular}

Table 1: ICT Devices available to respondent. 


\section{Food Science and Nutrition Technology}

\section{ICTs Capability for Transforming Agriculture and Creating Rural Income}

ICTs have the capability of creating income opportunities for user-farmers. This is seen in the numerous economic roles of ICT devices in the business and financial sectors. Table 2 showed that ICTs are used for product adverting with a mean score of 3.20; this is seen in the various awareness opportunities created by the use of several ICT tools to get people informed of both agricultural/household products/technologies. ICTs have the capability of delivering information about selling products $(\mathrm{M}=2.84)$, improving production systems $(\mathrm{M}=3.14)$, coordination planning of production $(\mathrm{M}=3.10)$, monitoring production of products $(\mathrm{M}=3.24)$, this is done through the various contacts made during, before and after production. It is also useful in assessing financial services $(M=3.91)$, alerting farm families of potential hazards $(M=3.50)$, increase technological literacy of farmers $(M=3.40)$ by helping them know available agriculture based products innovations many more.

\begin{tabular}{|c|c|c|}
\hline Capability Statement & Mean & SD \\
\hline Use for product advertising & 3.2 & 0.451 \\
\hline $\begin{array}{c}\text { Delivering information about selling } \\
\text { products }\end{array}$ & 2.84 & 0.552 \\
\hline $\begin{array}{c}\text { Improving interaction/communication } \\
\text { Developing local and national markets }\end{array}$ & 2.82 & 0.481 \\
\hline Identifying needs of consumers & 2.78 & 0.561 \\
\hline Improving production systems & 3.14 & 0.261 \\
\hline Coordination/planning of production & 3.1 & 0.281 \\
\hline Monitoring production of products & 3.24 & 0.314 \\
\hline Helps in assessing financial services & 3.91 & 0.784 \\
\hline $\begin{array}{c}\text { Helps in making sound production } \\
\text { decision }\end{array}$ & 3.01 & 0.641 \\
\hline Help farmers organize and plan input & 2.84 & 0.552 \\
\hline Access to knowledge based services & 2.7 & 0.321 \\
\hline Helps in keeping farm-records & 2.91 & 0.564 \\
\hline $\begin{array}{c}\text { Alerting farm families to potential } \\
\text { hazards }\end{array}$ & 3.5 & 0.781 \\
\hline Improve adaptive capacity of farmers & 2.69 & 0.881 \\
\hline $\begin{array}{c}\text { Increase technological literacy of } \\
\text { farmers }\end{array}$ & 3.4 & 0.78 \\
\hline Improve farmers bargaining power & 2.73 & 0.567 \\
\hline $\begin{array}{c}\text { Reduces farm management time and } \\
\text { drudgery }\end{array}$ & 3.01 & 0.61 \\
\hline Provides opportunity for micro-credit & 2.67 & 1.912 \\
\hline Creation of employment opportunities & 2.67 & 1.121 \\
\hline Reduces business transaction cost & 2.72 & 1.13 \\
\hline
\end{tabular}

Table 2: ICT Capability for improving Rural Income Capability.
Other ways of creating rural income includes reduction of transaction cost $(\mathrm{M}=2.72)$ which makes the farmer save more as less will be spent, creation of employment opportunities $(\mathrm{M}=2.67)$, reduces farm drudgery and time spent in farm operations $(M=3.01)$, improves adaptive capacity of farmers $(\mathrm{M}=2.69)$ developing local and national markets $(M=2.94)$ this helps farmers be better informed about best selling prices and time of such sales. The meaning of the above is that ICTs can be empowering for farmers, particularly poorly-endowed ones with limited assets and purchasing power, to the extent that these information and communication technologies: a. enable them to gain access to and control over more and better resources on favorable terms, which they can contribute to their own or others' production processes and for which they can get remuneratively compensated; $b$. inform them about and give them access to new or better technologies that can make their available resources more productive, and also better knowledge and skills for utilizing these technologies; and/or c. link them into organizations, formal or informal, that give them access on favorable terms to resources and technologies as well as to markets for their products, and also enable farmers' organizations to function more effectively, using their available resources and technologies more productively [22].

Farmers therefore, need technical as well as market information. Mwakaje [23] revealed that out of the surveyed 200 farmers in Tanzania, 23\% of them replied that they are using ICTs to find market information. ICTs, particularly mobile phones enable farmers to be on an equal footing with other actors. It facilitates power shifting or a change in the power balance between smallholder farmer's brokers and other actors in the value chains. ICTs are democratizing our communications; particularly appropriate mobile applications enhance market transparency and help to give a better return for farmers' produce. It enhances the visibility of farmers in the value chain and enables actors to play multiple roles in the value chains. After all, it adds value to farmers' efforts and returns.

Mobile phones serve all of the actors in the value chain. ICTs (mobile applications) are changing the way actors are communicating with each other. They can facilitate both vertical and horizontal communication both within and among institutions and actors. To put it in a Nutshell, mobile applications promote an inclusive value chain 


\section{Food Science and Nutrition Technology}

\begin{tabular}{|c|c|}
\hline Constraints & Percentage \\
\hline High cost of hardware & $98.50 \%$ \\
\hline Low level of education & 89.2 \\
\hline Lack of access to clean energy & 93.4 \\
\hline Language /cultural barrier & 89.2 \\
\hline Programmes not meeting needs & 91.5 \\
\hline Poor network coverage & 100 \\
\hline Low income of farmers & 89.2 \\
\hline Lack/absence of service shops & 71.3 \\
\hline Inadequate time for the farmers & 65.4 \\
\hline
\end{tabular}

Table 3: Constraints to ICT Use for Creating Rural Income.

\section{Constraints to ICT use for Creating Rural Income}

Despite the potentials of ICTs in creating rural income, the respondents faces certain problems such as high cost of hardware as indicated by $98.5 \%$ response, low level of education (89.2\%), lack of access to clean energy (93.4\%) language barrier (89.2\%), poor network coverage $(100 \%)$, low income of farmers $(89.2 \%)$, poor network coverage (100\%), low income of farmers(89.2\%), absenter of sensing shops (71.3\%) and inadequate time for the farmers $(65.4 \%)$. The cost of hardware is a key limitation, both in terms of basic phones for mobile money services and smart-phones for the use of more sophisticated products like the data collection application. It is also necessary to train the users on new technologies and processes. This can be logistically complex and costly as groups are geographically dispersed. The group demographics mean that those targeted often have low levels of education, which can make the delivery of training and information more complex.

Small-scale farmers in Africa face many problems that are often complex and multi-faceted. The most pronounced challenges facing small scale farmers included the farm sizes, which have been declining over time. Because of this factor, rural people have insufficient land to eke a living [24]. Some of the rural community members are landless or near landless, leading to major social and economic problems. The smallness of their lands leads to challenges of diseconomies of scale, and considering that most small-scale farmers are resourcepoor, they find it difficult to access affordable credit and inputs for their produce. Most of these farmers have little experience in produce marketing [25], and lack good and efficient markets [26-30]. Typical examples include the very high transport and transactional costs, small inefficient markets, low agricultural productivity, low levels of irrigation and erratic rainfall, vulnerability to high seasonal and inter-annual fluctuations, high rates of evapo-transpiration and very slow adoption of new technologies. Problems of this nature make the smallholder farm 'the global epicentre of extreme poverty' [3].

\begin{tabular}{|c|c|c|}
\hline Strategies & Mean & SD \\
\hline Training users on ICT & 3.21 & 0.674 \\
\hline Reducing cost of hardware & 3.12 & 0.555 \\
\hline Designing ICT to meet news of users & 3.4 & 0.441 \\
\hline Provision of modern energy & 3.48 & 1.134 \\
\hline Improve network coverage & 2.98 & 1.156 \\
\hline Better use of postal system & 2.76 & 0.471 \\
\hline Use of posters relevant to need & 2.89 & 1.115 \\
\hline $\begin{array}{c}\text { Regular meetings for information } \\
\text { sharing }\end{array}$ & 3 & 0.984 \\
\hline
\end{tabular}

Table 4: Strategies for Improved Use of ICT to Create Rural Income.

\section{Strategies for Improved use of ICT to Create Rural Income}

Table 4 showed the strategies that could be put in place to improve use of ICTs for income creation in the study area. These were training of users in ICTs $(M=3.21)$, reducing cost of hardware $(\mathrm{M}=3.12)$, designing ICTs to meet needs of users $(\mathrm{M}=3.40)$, provision of energy $(M=3.48)$, improve network coverage $(M=2.98)$, better use of postal services ( $\mathrm{M}=2.78)$, use of posters relevant to new $(M=2.89)$, and regular meetings for information sharing $(M=3.06)$.

\section{Conclusion}

ICTs have been found very effective in timely disseminating information needed by the farmers. The study suggested that maximum respondents were agreed that mobile and radio can be a useful source of agricultural information and a tool for creating rural income among women farmers in the study area. Despite the problems of electricity, network coverage, high cost of ICT devices, ICTs tools are important in creating rural farm incomes among respondents. The cost of ICT devices be reduced to encourage all manner of users, network be improved and electricity supplied adequately.

\section{References}

1. World Bank (2017) Mozambique.

2. Diao X, Hazell P, Resnick D, Thurlow J (2007) The role of agriculture in development: implications for Sub- 
Saharan Africa. IFPRI Report 153, IFPRI, Washington DC.

3. United Nations Development Programme (UNDP) (2005) Investing in development: apractical plan to achieve the Millennium Development Goals. JSTOR 36(2): 145-147.

4. Hirst JJJ, Overton B, Allen, Byron Y (1988) Small-scale agriculture. Australia Common wealth Geographic Bureau, Canberra.

5. Narayan S, Gulati A (2002) Globalization and smallholders: a review of issues, approaches and implications. IFPRI MSSD Discussion Paper 50.

6. Davis JR (2006) How can the poor benefit from the growing markets for high value agricultural products. National Resource Institute.

7. Food and Agriculture Organization of the United Nations (FAO) (2000) The role of information and communication technologies in rural development and food security. FAO, Rome.

8. Richardson D (1997) The internet and rural and agricultural development-an integrated approach. Rome.

9. Van Audenhove L (2003) Towards an integrated information society policy in South Africa:an overview of political rhetoric and policy initiatives 1994 - 2000. Communicatio 29(1-2): 129-147.

10. Livingston G, Schonberger S, Delaney S (2011) SubSaharan Africa: The State of Smallholder in Agriculture. Paper presented at the IFAD: Conference on New Directions for Smallholder Agriculture.

11. Munyua H, Adera E, Jensen M (2009) Emerging ICTs and Their Potential in Revitalizing Small- Scale Agriculture in Africa. World Conference on Agriculture Information and IT 2(1): 3-9.

12. IFAD (2008) Proceedings of the Governing Council Round Tables (3): Challenges and Opportunities for Smallholder Farmers in the Context of Climate Change and New Demands of Agriculture.

13. Aker, Jenny C (2011) Dial 'A' for Agriculture: a Review of Information and Communication Technologies for Agricultural Extension in Developing Countries. Agricultural Economics 42(6): 631-647.
14. Monchi L, Meng-Chun L (2006) ICT and Agricultural Productivity: Evidence from Cross-Country Data. Agricultural Economics 34(3): 221-228.

15. Muto M, Yamano T (2009) The Impact of Mobile Phone Coverage Expansion on Market Participation: Panel Data Evidence from Uganda. World Development 37(12): 1887-1896.

16. IMSG (2010) Education in Imo State. Imo State, Nigeria: Ministry of information, Owerri, Imo State Government.

17. Chavula KH (2014) The role of ICTs in agricultural productivity in Africa. Academic journals 6(7): 279289.

18. Anoop M, Ajjan N, Ashok KR (2015) ICT based market information servicesin Kerala - determinants and barriers of adoption. Econ Aff 60(1): 117-121.

19. Chhachhar AR, Querestic B, Khushk GM, Ahmed S (2014) Impact of ICTs in agriculture development. J Basic Appl Sci Res 4: 281-288.

20. Muddassir M, Jalip MW, Noor MA, Zia MA, Aldosri FO, et al. (2016) Farmers' perception of factors hampering maize yield in rain-fed region of Pind Dadan Khan, Pakistan. J Agric Ext 20(2): 1-17.

21. Otter V, Theuvsen L (2014) ICT and farm productivity: Evidence from the Chilean agricultural export sector. In GIL Jahrestagung, pp: 113-116.

22. Norman Uphoff (2012) Empowerment of Farmers through ICT. Draft paper for ECOSOC

23. Mwakaje A (2010) Information and communication technology for rural farmer's market access in Tanzania'. Journal of Information Technology Impact 10(2): 111-128.

24. Jayne TS, Yamano T, Weber M, Tschirley D, Benfica R, et al. (2001) Smallholder income and land distribution in Africa: implications for poverty reduction strategies. Michigan State University, Department of Agricultural Economics Michigan.

25. Mukhwana E, Nyongesa M, Ogemah V (2005) facilitating small-scale farmer collective marketing activities in Africa: the case of cereals banks in Kenya. Nairobi. 


\section{Food Science and Nutrition Technology}

26. Mukhebi A, Kundu J, Okolla A, Wambua M (2007) Linking farmers to markets through modern information and communication technologies in Kenya.

27. Workshops/Workshop_on_High_Value_Products_Oct_ 2005/global_issues_paper.pdf>.

28. National Population Commission (NPC) (2006) Official Population Report of South East Nigeria.
29. Richardson D (2006) ICTs - transforming agricultural extension. Report of the $6^{\text {th }}$ Consultative Expert Meeting of CTA's Observatory on ICTs.

30. Yared M (2015) ICTs in Linking Farmers to Markets: Innovative Mobile Applications and Lessons Learned from the Past and the Future.

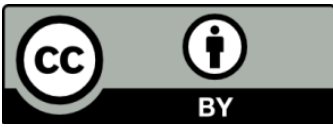

